\title{
The influence of soybean biodiesel and diesel on corrosion of SAE 1020 carbon steel.
}

The national demand for biodiesel is growing considerably and studies have been able to prove that biodiesel presents itself able to trigger corrosive processes on metal parts. This study aims to evaluate the SAE 1020 carbon steel corrosion rate by weight loss after accelerated aging in soybean biodiesel samples (B100) and in diesel with the addition of $5 \%$ biodiesel $(B 5 \mathrm{~S} 500)$ at storage temperature $\left(25^{\circ} \mathrm{C}\right)$ and engine operating temperature $\left(100^{\circ} \mathrm{C}\right)$, for a period of $10 \mathrm{consecutive} \mathrm{days.}$ The SAE 1020 carbon steel specimens $(12.5 \times 75 \times 3 \mathrm{~mm})$ were taken from the same steel plate, sanded, cleaned and degreased sequentially with alcohol $98 \%$ and $100 \%$ acetone and submitted to ultrasonic bath in $100 \%$ acetone for 180 seconds. After the corrosion test at $25^{\circ} \mathrm{C}$ and $100^{\circ} \mathrm{C}$, it was observed the formation of deposits corrosion in SAE 1020 carbon steel blades, in the cases of soybean biodiesel samples (B100) and diesel (B5 S500). After the test at $100^{\circ} \mathrm{C}$, it was also observed a color change, in the case of soybean biodiesel samples (B100). The SAE 1020 carbon steel corrosion rate, subjected to soybean biodiesel (B100) and diesel (B5 S500), increased with temperature, being more pronounced in the specimens subjected to corrosion tests with soybean biodiesel (B100).

Keywords: Biodiesel; SAE 1020 carbon steel; Corrosion.

\section{Influência do biodiesel e do diesel de soja na corrosão do aço carbono SAE 1020.}

\begin{abstract}
A demanda nacional por biodiesel está crescendo consideravelmente e estudos têm comprovado que o biodiesel se apresenta capaz de desencadear processos corrosivos em peças metálicas. Este trabalho tem como objetivo avaliar a taxa de corrosão do aço carbono SAE 1020 por perda de peso após envelhecimento acelerado em amostras de biodiesel de soja (B100) e em diesel com adição de $5 \%$ de biodiesel (B5 S500) à temperatura de armazenamento (25 ${ }^{\circ} \mathrm{C}$ ) e temperatura ambiente $\left(100^{\circ} \mathrm{C}\right)$, por um período de 10 dias consecutivos. As amostras de aço carbono SAE $1020(12,5 \times 75 \times 3$ mm) foram retiradas da mesma placa de aço, lixadas, limpas e desengorduradas sequencialmente com álcool $98 \%$ e $100 \%$ acetona e submetidas a banho ultrassônico em $100 \%$ de acetona por 180 segundos. Após o ensaio de corrosão a $25^{\circ} \mathrm{C}$ e $100^{\circ} \mathrm{C}$, observou-se a formação de depósitos de corrosão nas lâminas de aço carbono SAE 1020 , nos casos das amostras de biodiesel de soja (B100) e diesel (B5 S500). Após o teste a $100^{\circ} \mathrm{C}$, também foi observada uma mudança de cor, no caso das amostras de biodiesel de soja (B100). A taxa de corrosão do aço carbono SAE 1020, submetida ao biodiesel de soja (B100) e ao diesel (B5 S500), aumentou com a temperatura, sendo mais pronunciada nos corpos-de-prova submetidos ao teste de corrosão com biodiesel de soja (B100).
\end{abstract}

Palavras-chave: Biodiesel; Aço carbono SAE 1020; Corrosão.

Topic: Engenharia de Materiais

Reviewed anonymously in the process of blind peer.

Roberto Guimarães Pereira (iD

Universidade Federal Fluminense, Brasil http://lattes.cnpq.br/9607255646013062 http://orcid.org/0000-0001-6094-1396

temrobe@vm.uff.br

João Octávio Caranzano Moraes (iD

Universidade Federal Fluminense, Brasil

http://lattes.cnpq.br/9483380249337627

http://orcid.org/0000-0001-6515-4631

caranzano@hotmail.com

Juan Manuel Pardal ii

Universidade Federal Fluminense, Brasil http://lattes.cnpq.br/3583921436364162 http://orcid.org/0000-0001-9625-4547 juanpardal@vm.uff.br
Received: 07/10/2018

Approved: 08/11/2018
Referencing this:

PEREIRA, R. G.; MORAES, J. O. M.; PARDAL, J. M.. The influence of soybean biodiesel and diesel on corrosion of SAE 1020 carbon steel. Revista Ibero-Americana de Ciências Ambientais, v.9, n.8, p.158-167, 2018. DOI: http://doi.org/10.6008/CBPC2179-6858.2018.008.0014 


\section{INTRODUTION}

The corrosion of materials by different agents is an important subject with application in different areas, such as: cosmetic; pipelines; concrete; automotive and fuels (HAYASHI, 1991; TAKAO et al., 1991; CHAOUCHE et al., 2011; OKA, 1986; GENG et al., 2009). The present study aims to investigate the corrosion of SAE 1020 carbon steel when exposed to soybean biodiesel (B100) and commercial diesel (B5 S500 - diesel with $5 \%$ of biodiesel and maximum of $500 \mathrm{ppm}$ of sulfur) at different test temperatures.

Due to the problems related to shortages and environmental damage generated by the use of fossil fuels and the impossibility of direct use of vegetable oils in engines, researchers have invested resources in finding some alternatives. Biodiesel is an alternative fuel that is becoming accepted in a steadily growing number of countries around the world (KNOTHE, 2005; DERMIBAS, 2009; PEREIRA et al., 2007; PEREIRA et al., 2011; PEREIRA et al., 2012; PEREIRA et al., 2014; GÜLÜM et al., 2015; ALMEIDA et al., 2015; ÖZTÜRK, 2015; CAl et al., 2015; NAUTIYAL et al., 2014; GIWA et al., 2014)

Brazil is a privileged country presenting large arable land area and wide variety of oil believed to be potential sources of convertible vegetable oils into biodiesel. In the country there are, for example the production of: soybean; castor; cotton; sunflower; peanuts; canola and palm, in addition to jatropha curcas, babussu and macaúba (PERES, 2006).

\section{THEORETICAL REVIEW}

\section{Soybean production}

Vegetable oils are obtained predominantly from grains of different plant species. The oil extraction can be made by physical process (pressing) or chemical (solvent). The solvent extraction produces better results, but the more traditional way is physical extraction, which uses mechanical and hydraulic presses to crush the grains. A mixed extraction (mechanical/solvent) can also be done. Selecting the type of extraction depends on two factors: the productive capacity and oil content.

Soybean (Glycine max (L.) Merrill) is a very versatile grain that gives rise to products widely used by agro-chemical industry and food industry. Besides is a raw material for extraction of oil for biofuel production. Soybean has about $25 \%$ of oil content in grain. In the agribusiness world, soybean production is, among the economic activities in recent decades, the most prominent. This can be attributed to several factors, such as structuring of a large international market related to trade in products of soybean, oilseed consolidation as an important source of vegetable protein and increased development and delivery of technologies that made possible the expansion of soy exploration for various regions of the world.

The largest producers of soybeans are: United States of America, Brazil, Argentina, India and China. According to FAO (2018), in 2016, the soybean world production was around $335 \times 10^{6} \mathrm{t}$ in a harvested area of $122 \times 10^{6}$ ha corresponding a yield of 2.7 t. ha $^{-1}$. According to FAO (2018), in 2016, Brazil was: the second country in soybean production with 96296714 t; the second country in harvested area with 33153679 ha and the thirteenth country in yield with 2.9046 t.ha $^{-1}$ (table 1, table 2 and table 3 ). 
Table 1: Soybean production in 2016 (top 10).

\begin{tabular}{|c|c|}
\hline Country & Soybean area harvested in 2016 (ha) \\
\hline United States of America & 33482430 \\
\hline Brazil & 33153679 \\
\hline Argentina & 19504648 \\
\hline India & 11500000 \\
\hline China, mainland & 6639113 \\
\hline Paraguay & 3370000 \\
\hline Canada & 2190500 \\
\hline Russian Federation & 2120014 \\
\hline Ukraine & 1859400 \\
\hline Bolivia & 1336399 \\
\hline
\end{tabular}

Table 3: Soybean yield in 2016 (top 15).

\begin{tabular}{|c|c|}
\hline Country & Soybean yield in 2016 (t.ha-1) \\
\hline Turkey & 4.3219 \\
\hline Georgia & 3.7592 \\
\hline Italy & 3.7539 \\
\hline Egypt & 3.5006 \\
\hline Serbia & 3.5000 \\
\hline Greece & 3.1610 \\
\hline Croatia & 3.1112 \\
\hline Austria & 3.1047 \\
\hline Argentina & 3.0648 \\
\hline Slovenia & 3.0146 \\
\hline Spain & 2.9955 \\
\hline Brazil & 2.9815 \\
\hline Germany & 2.9046 \\
\hline Belize & 2.7333 \\
\hline
\end{tabular}

\section{Biodiesel background}

Biodiesel is known as monoalkyl, such as methyl and ethyl, esters of fatty acids. Biodiesel can be produced from a number of sources, including recycled waste vegetable oil, oil crops, animal fats and algae oil. Biodiesels play an important role in meeting future fuel requirements in view of their nature (less toxic), and have an edge over conventional diesel as they are obtained from renewable sources (DEMIRBAS, 2009).

The regulations for biodiesel have been developed in different countries where its use is permitted. In the USA, the standard for biodiesel is set by the technical standard ASTM D 6751, the European Union is related with the standard EN 14214 and in Brazil is set by the ANP (National Agency of Petroleum, Natural Gas and Biofuels) resolution n.45 from 25.08.2014.

The transesterification process is used to transform triglycerides into esters, or biodiesel. In the process of transesterification, the triglycerides found in different kinds of oils and fats react with alcohol, usually methanol or ethanol to produce esters and glycerin. For the reaction to occur it is necessary to use a catalyst. In the transesterification process, a triglyceride molecule reacts with an alcohol molecule causing the separation of one of the fatty acids of the triglyceride, producing a diglyceride and an ester.

This diglyceride reacts with a second molecule of alcohol that takes another fatty acid, forming a second ester and a monoglyceride. Finally, a third molecule of alcohol reacts with the monoglyceride, forming the third ester and a molecule of glycerin. The reactions occurring are reversible, and the stoichiometric ratio is three moles of alcohol for each mole of oil being processed. The reaction can be carried out with 
concentrations of alcohol in excess, as this reduces time and increases the conversion efficiency of the process (LANG et al., 2001).

The transesterification process using methanol and base catalyst is the most commonly used to produce biodiesel. The catalysts commonly used are sodium hydroxide $(\mathrm{NaOH})$ or potassium hydroxide $(\mathrm{KOH})$. The catalyst is diluted in alcohol and then added the oil. The product is ester (biodiesel) and crude glycerin which is separated from the ester by decanting or centrifuging. Repeated washing processes are performed by adding acidified water in the reaction products. This mixture is stirred lightly and serves to remove residual glycerine soap, catalyst and serves as a neutralising agent of the fuel. The washing process is repeated until the biodiesel becomes clear. The main drawbacks of the process are the presence of water on some of the reagents and the high level of Free Fatty Acids (FFA) in the raw material. In both cases, the transesterification reaction is replaced by a saponification reaction.

The transesterification process can also be developed using acid catalysts and non-homogeneous catalysts. In the case of acid catalysts, the process time is longer, but do not have drawbacks with the water content and FFA. In the case of non-homogeneous catalysts, these bring benefits to: reducing the washing process; product separation and reuse of catalysts. According to National Agency of Petroleum, Natural Gas and Biofuels (ANP), the Brazilian production of biodiesel in august 2018 reached $486156 \mathrm{~m}^{3}$ and the main raw materials used to produce biodiesel were soybean oil $(74,14 \%)$ and beef tallow $(11,80 \%)$. The total production of biodiesel in Brazil in 2017 was $4289856 \mathrm{~m}^{3}$ (ANP, 2018).

In Brazil, biodiesel must comply with ANP quality specifications in its Resolution n.45 of 25.08.2014. It can be used pure or mixed with diesel in various proportions. The percentage of biodiesel mixed with diesel is indicated by the number after letter B. The mixture of $2 \%$ biodiesel to petroleum diesel is called B2 and so on, up to pure biodiesel, called B100. Federal Law 11,097/2005 that introduced biodiesel determined consecutive increases in the blend with diesel, delegating authority to the ANP to regulate and supervise the commercialization of biofuels. Currently, the percentage is $10 \%$ (B10) started in March 2018, according to the text of Law 13,263 of 23.03 .2016 .

Biodiesel has become more attractive as alternative fuel for automobiles because of its environmental benefits and the fact that it is made from renewable sources. However, corrosion of metals in biodiesel is one of the concerns related to biodiesel compatibility issues (Haseeb et al., 2010a). Studies have been able to prove that, despite having numerous social, economic and environmental advantages over diesel, biodiesel is less stable and more susceptible to oxidation reactions. Thus, biodiesel would be corrosive and prone to degradation caused by moisture absorption and oxidation during storage (MCCORMICK et al., 2007; HASEEB et al., 2010b; FAZAL et al., 2011a), besides microorganisms action.

\section{MATERIALS AND METHODS}

The soybean biodiesel used in this work was produced and donated by GrandValle Bioenergy Company, Brazil, and is within the standards established by Resolution n.45, from 25.08 .2014 , specified by 
ANP Technical Regulation n.3/2014. The diesel used in the research was the B5 S500 diesel commercialized by Shell Brazil. This fuel has addition of $5 \%$ biodiesel and maximum sulfur content of $500 \mathrm{ppm}$.

The test coupons were prepared in accordance with ASTM D130/12. All of them were made from the same steel plate and cut into shaped blades, having dimensions of $12.5 \times 75 \times 3 \mathrm{~mm}$. Before immersion, the test coupons were treated as follow: polished with silicon carbide abrasive papers (grade 240), then washed and degreased with alcohol $98 \%$ and acetone 100\%. These were then dried with hot air, identified and submitted to ultrasonic bath with acetone $100 \%$ for 180 seconds. After ultrasound bath, the samples were dried with hot air until any residual acetone was evaporated. Later, they were weighed on analytical balance of four decimal places. After cleaning, the corrosion tests were performed.

All corrosion tests were conducted meeting the requirements of ASTM D130/12. The corrosion tests were performed at room temperature $\left(25^{\circ} \mathrm{C}\right)$ and $100^{\circ} \mathrm{C}$. All baths corrosion, both at $25^{\circ} \mathrm{C}$ and $100^{\circ} \mathrm{C}$, were performed in triplicate for 240 consecutive hours. In the test at room temperature $\left(25^{\circ} \mathrm{C}\right)$, the samples were submerged in $30 \mathrm{ml}$ of B5 S500 diesel and B100 soybean biodiesel.

After immersion, the samples were sealed and protected from solar radiation and the outdoor humidity, and maintained under these conditions for 240 hours (10 consecutive days) and then analyzed. In the test at temperature of $100^{\circ} \mathrm{C}$, the test coupons were submerged in test tubes of $25 \mathrm{~mm}$ diameter and 150 $\mathrm{mm}$ long, containing $30 \mathrm{ml}$ of fuel (B100 soybean biodiesel or B5 S500 diesel) and placed in low stainless steel pressure pump with a removable neoprene gasket on the cover, and resistant to pressure. Low-pressure pumps containing test tubes with fuel in question and the samples were inserted into the corrosion bath stabilized at $100^{\circ} \mathrm{C}$.

After completion of the consecutive 240 hours of testing, the samples were removed, dried and weighed to check training and deposits and possible mass gain. Subsequently, the samples surface was cleaned, deeply cleaned (ultrasound bath), dried and weighed again to check the possible loss of mass for the calculation of the uniform corrosion rate. The obtained data from weight loss was converted into corrosion rate (mpy) using the equation (FONTANA, 1987).

It has: $\mathrm{mpy}=(\mathrm{W} \times 534) /(\rho \times \mathrm{t} \times \mathrm{A})$, where: $\mathrm{mpy}$ stands for mils $(0.0254 \mathrm{~mm})$ penetration per year; $\mathrm{W}$ is the weight loss $(\mathrm{mg}) ; \rho$ is the density $\left(\mathrm{g} / \mathrm{cm}^{3}\right)$; $\mathrm{A}$ is the exposed surface area $\left(\mathrm{in}^{2}\right)$ and $\mathrm{t}$ is the exposure time (h). The mils penetration per year is a corrosion rate widely used. The rate of penetration can be used to predict the life of a given component (FONTANA, 1987).

\section{RESULTS AND DISCUSSION}

The characteristics of B100 soybean biodiesel used in the tests are presented in table 4 . Table 5 shows the mean values of the corrosion deposits formed after 10 days in the corrosion test, according to the fuel used and the test temperature. It was observed that the test coupons submitted to corrosion tests with B100 soybean biodiesel had higher deposit formation and that this increase also was proportional to the increase of test temperature. 
Table 4: Characteristics of B100 soybean biodiesel used in the tests.

\begin{tabular}{|l|c|c|c|c|}
\hline \multicolumn{1}{|c|}{ Properties } & Units & Methods & Brazilian Limits & Results \\
\hline Density, $20^{\circ} \mathrm{C}$ & $\mathrm{Kg} / \mathrm{m}^{3}$ & ASTM D4052 & $850-900$ & 881.9 \\
\hline Kinematic Viscosity, $40^{\circ} \mathrm{C}$ & $\mathrm{mm}^{2} / \mathrm{s}$ & ASTM D445 & $3.0-6.0$ & 4.37 \\
\hline Flash Point & ${ }^{\circ} \mathrm{C}$ & ASTM D93 & Min.: $100^{\circ} \mathrm{C}$ & 172 \\
\hline Ester content & $\% \mathrm{~m} / \mathrm{m}$ & EN 14103 & Min.: 96.5 & 99.8 \\
\hline Carbon Residue & $\% \mathrm{~m} / \mathrm{m}$ & ASTM D4530 & 0.050 & 0.040 \\
\hline Sulfated Ash & $\% \mathrm{~m} / \mathrm{m}$ & ASTM D874 & Max.: 0.02 & $<0.02$ \\
\hline Sulfur & $\mathrm{mg} / \mathrm{Kg}$ & NBR 15867 & Max.: 10 & $<0.01$ \\
\hline Sodium + Potassium & $\mathrm{mg} / \mathrm{Kg}$ & NBR 15553 & Max.: 5 & $<0.01$ \\
\hline Calcium + Magnesium & $\mathrm{mg} / \mathrm{Kg}$ & NBR 15553 & Max.: 5 & $<0.01$ \\
\hline Phosphorus content & $\mathrm{mg} / \mathrm{Kg}$ & NBR 15553 & Max.: 10 & $<0.01$ \\
\hline Copper Strip Corrosion & - & ASTM D130 & Max.: 1 & 1 \\
\hline Cold Filter Plugging Point & ${ }^{\circ} \mathrm{C}$ & ASTM D6371 & Max.: 19 & -15 \\
\hline Acid Number & $\mathrm{mgKOH} / \mathrm{g}$ & ASTM D664 & Max.: 0.50 & 0.5 \\
\hline Free Glycerol & $\% \mathrm{~m} / \mathrm{m}$ & ASTM D6584 & Max.: 0.02 & 0.0015 \\
\hline Total Glycerol & $\% \mathrm{~m} / \mathrm{m}$ & ASTM D6584 & Max.: 0.25 & 0.1547 \\
\hline Monoglycerides & $\% \mathrm{~m} / \mathrm{m}$ & ASTM D6584 & Max.: 0.70 & 0.5500 \\
\hline Diglycerides & $\% \mathrm{~m} / \mathrm{m}$ & ASTM D6584 & Max.: 0.20 & 0.0609 \\
\hline Triglycerides & $\% \mathrm{~m} / \mathrm{m}$ & ASTM D6584 & Max.: 0.20 & 0.0152 \\
\hline Ethanol or Methanol Content & $\% \mathrm{~m} / \mathrm{m}$ & EN 14110 & Max.: 0.20 & 0.006 \\
\hline lodine value & $\mathrm{g} / 100 \mathrm{~g}$ & EN 14111 & Report & 133.3 \\
\hline
\end{tabular}

Table 5: Mean values of the corrosion deposits formed after 10 days in the corrosion test.

\begin{tabular}{|c|c|c|c|c|}
\hline Test Coupon Number & Fuel & $\begin{array}{c}\text { Temperature } \\
\left({ }^{\circ} \mathbf{C}\right)\end{array}$ & $\begin{array}{c}\text { Deposit } \\
(\mathbf{g})\end{array}$ & Mean Deposit (g) \\
\hline 25 & B5 S500 diesel & 25 & 0.0004 & \multirow{2}{*}{0.00043} \\
\hline 26 & B5 S500 diesel & 25 & 0.0004 & \multirow{2}{*}{0.00070} \\
\hline 27 & B5 S500 diesel & 25 & 0.0005 & \\
\hline 10 & B5 S500 diesel & 100 & 0.0007 & \multirow{2}{*}{0.00110} \\
\hline 11 & B5 S500 diesel & 100 & 0.0006 & \\
\hline 22 & B5 S500 diesel & 100 & 0.0008 & \multirow{2}{*}{0.00190} \\
\hline 23 & B100 soybean biodiesel & 25 & 0.0009 & \multirow{2}{*}{0} \\
\hline 12 & B100 soybean biodiesel & 25 & 0.0011 & \\
\hline 20 & B100 soybean biodiesel & 25 & 0.0013 & \\
\hline
\end{tabular}

After the corrosion test at $100^{\circ} \mathrm{C}$, the soybean biodiesel (B100) samples changed the color and appearance while in diesel samples no visual change was observed. Table 6 shows weight loss values (W) of the test coupons submitted to corrosion tests at different temperatures for 10 consecutive days. It was observed that the higher testing temperature and the higher concentration of biodiesel cause the higher values of W.

Table 6: Weight loss values (W) of the test coupons submitted to corrosion tests at different temperatures for 10 consecutive days.

\begin{tabular}{|c|c|c|c|}
\hline $\begin{array}{c}\text { Test Coupon } \\
\text { Number }\end{array}$ & Fuel & $\begin{array}{c}\text { Temperature } \\
\left({ }^{\circ} \mathbf{C}\right)\end{array}$ & $\begin{array}{c}\text { W } \\
(\mathbf{m g})\end{array}$ \\
\hline 25 & B5 S500 diesel & 25 & 0.2 \\
\hline 26 & B5 S500 diesel & 25 & 0.2 \\
\hline 27 & B5 S500 diesel & 25 & 0.4 \\
\hline 10 & B5 S500 diesel & 100 & 0.4 \\
\hline 11 & B5 S500 diesel & 100 & 0.3 \\
\hline 12 & B5 S500 diesel & 25 & 0.4 \\
\hline 22 & B100 soybean biodiesel & 25 & 0.4 \\
\hline 23 & B100 soybean biodiesel & 25 & 0.5 \\
\hline 24 & B100 soybean biodiesel & 100 & 0.7 \\
\hline 19 & B100 soybean biodiesel & 100 & 1.0 \\
\hline 20 & B100 soybean biodiesel & 100 & 0.9 \\
\hline 21 & B100 soybean biodiesel & & 0.9 \\
\hline
\end{tabular}


It was noted in this study that the corrosion rates of SAE 1020 carbon steel test coupons submitted to 10 consecutive days corrosion tests in the presence of $\mathrm{B} 100$ soybean biodiesel at room temperature $\left(25^{\circ} \mathrm{C}\right)$ and $100^{\circ} \mathrm{C}$ were higher than the corrosion rates of the test coupons submitted to corrosion tests in the presence of B5 S500 diesel. It was also observed that in the case of biodiesel and diesel, the corrosion rates increase with the increase of temperature (table 7 and figure 1). This behavior is in accordance with other works found in the literature that used different materials and biodiesel (HASEEB et al., 2010a; FAZAL et al., 2011a; HU et al., 2012; SINGH et al., 2012).

Table 7: Corrosion rates of SAE 1020 carbon steel coupons after 10 consecutive days corrosion test.

\begin{tabular}{|c|c|c|c|}
\hline $\begin{array}{c}\text { Test Coupon } \\
\text { Number }\end{array}$ & $\begin{array}{c}\text { Temperature } \\
\left({ }^{\circ} \mathbf{C}\right)\end{array}$ & Fuel & $\begin{array}{c}\text { Corrosion Rate } \\
\text { (mpy) }\end{array}$ \\
\hline 25 & 25 & B5 S500 diesel & 0.01499 \\
\hline 26 & 25 & B5 S500 diesel & 0.01496 \\
\hline 27 & 25 & B5 S500 diesel & 0.02976 \\
\hline 22 & 25 & B100 soybean biodiesel & 0.02997 \\
\hline 23 & 25 & B100 soybean biodiesel & 0.03698 \\
\hline 24 & 25 & B100 soybean biodiesel & 0.05206 \\
\hline 10 & 100 & B5 S500 diesel & 0.02999 \\
\hline 11 & 100 & B5 S500 diesel & 0.02241 \\
\hline 12 & 100 & B5 S500 diesel & 0.03032 \\
\hline 19 & 100 & B100 soybean biodiesel & 0.07598 \\
\hline 20 & 100 & B100 soybean biodiesel & 0.06725 \\
\hline 21 & 100 & B100 soybean biodiesel & 0.06822 \\
\hline
\end{tabular}

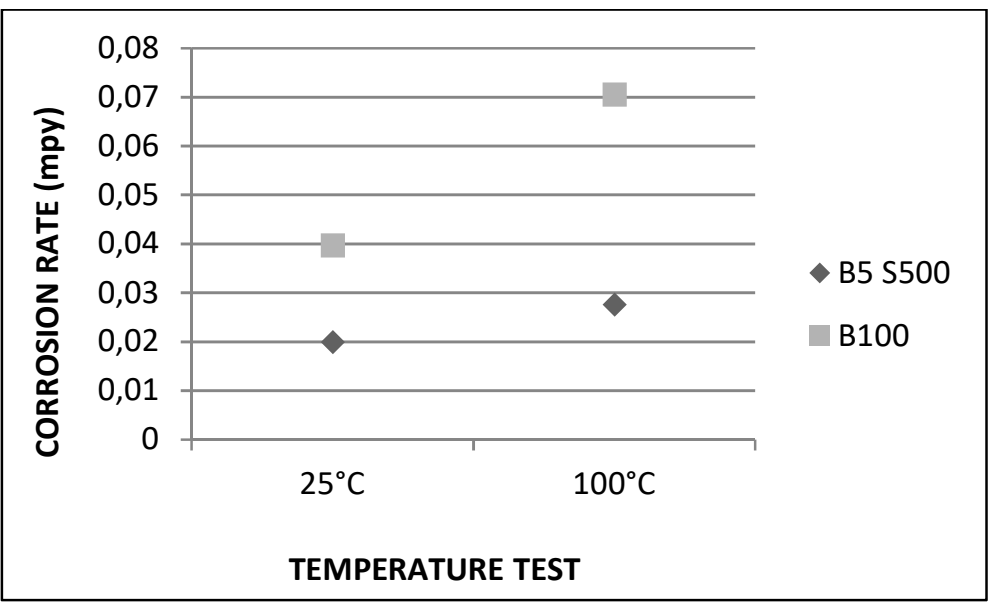

Figure 1: Average corrosion rates of SAE 1020 carbon steel coupons after 10 consecutive days corrosion test.

Table 8 summarizes results from different researches concerning the corrosion rates for different materials exposed to diesel and biodiesel (static immersion tests). In general it can be concluded that: the average corrosion rate in the case of biodiesel is greater than the diesel one; the average corrosion rate increases with the increase of temperature; materials such as: copper; magnesium; aluminum; brass; leaded bronze exhibit greater values of the average corrosion rate than steel carbon and cast iron.

Table 8: Average corrosion rates for different material exposed to diesel and biodiesel (static immersion tests).

\begin{tabular}{|c|c|c|c|c|c|}
\hline Fuel & Material & $\begin{array}{c}\text { Temperature } \\
{ }^{\circ} \mathbf{C}\end{array}$ & Test Hours & Average Corrosion Rate (mpy) & Reference \\
\hline B5 S500 Diesel & SAE 1020 Carbon Steel & 25 & 240 & 0.01990 \\
\hline B100 Soybean Biodiesel & SAE 1020 Carbon Steel & 25 & 240 & 0.03967 \\
\hline B5 S500 Diesel & SAE 1020 Carbon Steel & 100 & 240 & 0.02757 & Present work \\
\hline B100 Soybean Biodiesel & SAE 1020 Carbon Steel & 100 & 240 & 0.07048 \\
\hline B0 Diesel & Mild Steel & 27 & 1200 & 0.046 \\
\hline B100 Palm Biodiesel & Mild Steel & 27 & 1200 & Present work \\
\hline B0 Diesel & Mild Steel & 80 & 1200 & 0.052 & Fazal et al., 2011a \\
\hline
\end{tabular}




\begin{tabular}{|c|c|c|c|c|c|}
\hline B100 Palm Biodiesel & Mild Steel & 80 & 1200 & 0.059 & Fazal et al., 2011a \\
\hline B0 Diesel & Piston Metal & $\begin{array}{c}\text { Ambient temperature } \\
\left(15-40^{\circ} \mathrm{C}\right)\end{array}$ & 7200 & 0.0058 & Kaul et al., 2007 \\
\hline B100 Jatropha Curcas Biodiesel & Piston Metal & $\begin{array}{c}\text { Ambient temperature } \\
\left(15-40^{\circ} \mathrm{C}\right)\end{array}$ & 7200 & 0.0117 & Kaul et al., 2007 \\
\hline B100 Karanja Diessel & Piston Metal & $\begin{array}{c}\text { Ambient temperature } \\
\left(15-40^{\circ} \mathrm{C}\right)\end{array}$ & 7200 & 0.0058 & Kaul et al., 2007 \\
\hline B100 Mahua Biodiessel & Piston Metal & $\begin{array}{c}\text { Ambient temperature } \\
\left(15-40^{\circ} \mathrm{C}\right)\end{array}$ & 7200 & 0.0058 & Kaul et al., 2007 \\
\hline B100 Salvadora Biodiesel & Piston Metal & $\begin{array}{c}\text { Ambient temperature } \\
\left(15-40^{\circ} \mathrm{C}\right)\end{array}$ & 7200 & 0.1236 & Kaul et al., 2007 \\
\hline B0 Diesel & Copper & 60 & 840 & 0.036 & Haseeb et al., 2010a \\
\hline B100 Palm Biodiesel & Copper & 60 & 840 & 0.053 & Haseeb et al., $2010 a$ \\
\hline B0 Diesel & Leaded Bronze & 60 & 840 & 0.017 & Haseeb et al., $2010 a$ \\
\hline B100 Palm Biodiesel & Leaded Bronze & 60 & 840 & 0.0248 & Haseeb et al., 2010a \\
\hline B100 Palm Biodiesel & Aluminum & $\begin{array}{c}\text { Room temperature } \\
\left(25-27^{\circ} \mathrm{C}\right)\end{array}$ & 720 & 0,1230 & Chew et al., 2013 \\
\hline B100 Palm Biodiesel & Aluminum & $\begin{array}{c}\text { Room temperature } \\
\left(25-27^{\circ} \mathrm{C}\right)\end{array}$ & 1440 & 0.0527 & Chew et al., 2013 \\
\hline B100 Palm Biodiesel & Magnesium & $\begin{array}{c}\text { Room temperature } \\
\left(25-27^{\circ} \mathrm{C}\right)\end{array}$ & 720 & 3.0910 & Chew et al., 2013 \\
\hline B100 Palm Biodiesel & Magnesium & $\begin{array}{c}\text { Room temperature } \\
\left(25-27^{\circ} \mathrm{C}\right)\end{array}$ & 1440 & 2.6563 & Chew et al., 2013 \\
\hline B100 Palm Biodiesel & Cast Iron & Room temperature & 1200 & 0.0771 & Fazal et al., 2011b \\
\hline B0 Diesel & Cast Iron & $\begin{array}{l}\text { Room temperature } \\
\left(25-27^{\circ} \mathrm{C}\right)\end{array}$ & 2880 & 0.0774 & Fazal et al., 2012 \\
\hline B100 Palm Biodiesel & Cast Iron & $\begin{array}{c}\text { Room temperature } \\
\left(25-27^{\circ} \mathrm{C}\right)\end{array}$ & 2880 & 0.1122 & Fazal et al., 2012 \\
\hline B0 Diesel & Copper & $\begin{array}{c}\text { Room temperature } \\
\left(25-27^{\circ} \mathrm{C}\right)\end{array}$ & 2880 & 0.1583 & Fazal et al., 2012 \\
\hline B100 Palm Biodiesel & Copper & $\begin{array}{c}\text { Room temperature } \\
\left(25-27^{\circ} \mathrm{C}\right)\end{array}$ & 2880 & 0.3928 & Fazal et al., 2012 \\
\hline B0 Diesel & Aluminum & $\begin{array}{c}\text { Room temperature } \\
\left(25-27^{\circ} \mathrm{C}\right)\end{array}$ & 2880 & 0.0840 & Fazal et al., 2012 \\
\hline B100 Palm Biodiesel & Aluminum & $\begin{array}{c}\text { Room temperature } \\
\left(25-27^{\circ} \mathrm{C}\right)\end{array}$ & 2880 & 0.1730 & Fazal et al., 2012 \\
\hline B0 Diesel & Brass & $\begin{array}{c}\text { Room temperature } \\
\left(25-27^{\circ} \mathrm{C}\right) \\
\end{array}$ & 2880 & 0.1201 & Fazal et al., 2012 \\
\hline B100 Palm Biodiesel & Brass & $\begin{array}{c}\text { Room temperature } \\
\left(25-27^{\circ} \mathrm{C}\right)\end{array}$ & 2880 & 0.2099 & Fazal et al., 2012 \\
\hline B0 Diesel & Aluminum & 80 & 600 & 0.1000 & Norouzi et al., 2012 \\
\hline B100 Rapeseed Biodiesel & Aluminum & 80 & 600 & 0.3529 & Norouzi et al., 2012 \\
\hline B0 Diesel & Copper & 80 & 600 & 0.3235 & Norouzi et al., 2012 \\
\hline B100 Rapeseed Biodiesel & Copper & 80 & 600 & 0.9198 & Norouzi et al., 2012 \\
\hline $\begin{array}{c}\text { B100 } \\
\text { Commercial Biodiesel }\end{array}$ & Brass & Room temperature & 120 & 0.8661 & Aquino et al., 2012 \\
\hline $\begin{array}{c}\text { B100 } \\
\text { Commercial Biodiesel }\end{array}$ & Copper & Room temperature & 120 & 0.2283 & Aquino et al., 2012 \\
\hline B100 Palm Biodiesel & Copper & $\begin{array}{c}\text { Room temperature } \\
\left(25-27^{\circ} \mathrm{C}\right)\end{array}$ & 200 & 0.3513 & Fazal et al., 2013 \\
\hline B100 Palm Biodiesel & Copper & $\begin{array}{c}\text { Room temperature } \\
\left(25-27^{\circ} \mathrm{C}\right)\end{array}$ & 300 & 0.4119 & Fazal et al., 2013 \\
\hline B100 Palm Biodiesel & Copper & $\begin{array}{c}\text { Room temperature } \\
\left(25-27^{\circ} \mathrm{C}\right)\end{array}$ & 600 & 0.6057 & Fazal et al., 2013 \\
\hline B100 Palm Biodiesel & Copper & $\begin{array}{c}\text { Room temperature } \\
\left(25-27^{\circ} \mathrm{C}\right)\end{array}$ & 1200 & 0.6541 & Fazal et al., 2013 \\
\hline B100 Palm Biodiesel & Copper & $\begin{array}{l}\text { Room temperature } \\
\qquad\left(25-27^{\circ} \mathrm{C}\right)\end{array}$ & 2880 & 0.5330 & Fazal et al., 2013 \\
\hline
\end{tabular}

Table 9 shows the average corrosion rates (the mean values of the corrosion rates shown in table 7) and the average thickness loss values $(\mathrm{mm})$ calculated for the lifespan (20 years) of SAE 1020 carbon steel samples submitted to corrosion tests with B5 S500 diesel samples and B100 soybean biodiesel at temperatures of $25^{\circ} \mathrm{C}$ and $100^{\circ} \mathrm{C}$. These values represent an outstanding relative corrosion resistance $(<$ $1 \mathrm{mpy}$ ) using as reference the values shown by Fontana (1987) based on typical ferrous and nickel-based alloys.

Table 9: Average thickness loss values $(\mathrm{mm})$ calculated for the lifespan (20 years) of SAE 1020 carbon steel samples.

\begin{tabular}{|c|c|c|c|}
\hline $\begin{array}{c}\text { Temperature } \\
{ }^{\circ} \mathrm{C}\end{array}$ & Fuel & $\begin{array}{c}\text { Average corrosion rate } \\
(\mathbf{m p y})\end{array}$ & $\begin{array}{c}\text { Average thickness loss in 20 years } \\
(\mathbf{m m})\end{array}$ \\
\hline 25 & B5 S500 diesel & 0.01990 & 0.0101 \\
\hline 25 & B100 soybean biodiesel & 0.03967 & 0.0201 \\
\hline
\end{tabular}




\begin{tabular}{|l|c|c|c|}
\hline 100 & B5 S500 diesel & 0.02757 & 0.0140 \\
\hline 100 & B100 soybean biodiesel & 0.07048 & 0.0358
\end{tabular}

\section{CONCLUSIONS}

The effect of temperature on the corrosion of SAE 1020 carbon steel in B100 soybean biodiesel and B5 S500 diesel was investigated. The corrosive attack on the surfaces of the test coupons submitted to B100 soybean biodiesel are more evident than in test coupons submitted to B5 S500 diesel. The specimens submitted to corrosion tests in the presence of B100 soybean biodiesel had a higher formation of corrosion deposits on their surfaces than the specimens submitted to corrosion tests in the presence of B5 S500 diesel. This increase in the formation of corrosion deposits also was evident with increasing test temperature. The SAE 1020 carbon steel corrosion rate, submitted to both fuels, increased with temperature.

This increase was more pronounced in test coupons submitted to B100 soybean biodiesel. After literature search, it was observed the lack of published studies on the corrosive potential of soybean biodiesel on SAE 1020 carbon steel, limiting the comparison of this study with other results, thus highlighting the need for further research in the area.

\section{REFERENCES}

ALMEIDA, V. F.; GARCÍA-MORENO, P. J.; GUADIX, A.; GUADIX, E. M.. Biodiesel production from mixtures of waste fish oil, palm oil and waste frying oil: Optimization of fuel properties. Fuel Processing Technology, v.133, p.152-160, 2015. DOI: https://doi.org/10.1016/j.fuproc.2015.01.041

ANP. Agência Nacional do Petróleo, Gás Natural e Biocombustíveis. Informação de Mercado. Brasília: ANP, 2018

AQUINO, I. P.; HERNANDEZ, R. P. B.; CHICOMA, D. L.; PINTO, H. P. F.; AOKI, I. V.. Influence of light, temperature and metallic ions on biodiesel degradation and corrosiveness to copper and brass. Fuel, v.102, p.795-807, 2012. DOI: https://doi.org/10.1016/i.fuel.2012.06.011

CAI, Z. Z.; WANG, Y.; TENG, Y. L.; CHONG, K. M.; WANG, J. W.; ZHANG, J. W.; YANG, D. P.. A two-step biodiesel production process from waste cooking oil via recycling crude glycerol esterification catalyzed by alkali catalyst. Fuel Processing Technology, v.137, p.186-193, 2015. DOI: https://doi.org/10.1016/i.fuproc.2015.04.017

CHAOUCHE, S. B.; LOUNIS, A.; NEZZAL, G.. Effect of microstructure on corrosion resistance of pipelines steels buried in alkaline soil. International Journal of Microstructure and Materials Properties, v.6, n.6, p.526542, 2011. DOI:

https://doi.org/10.1504/IJMMP.2011.044369

CHEW, K. V.; HASEEB, A. S. M. A.; MASJUKI, H. H.; FAZAL, M. A.; GUPTA, M.. Corrosion of magnesium and aluminum in palm biodiesel: A comparative evaluation. Energy, v.57, p.478-483, 2013. DOI:

https://doi.org/10.1016/i.energy.2013.04.067

DEMIRBAS, A.. Biofuels securing the planet's future energy needs. Energy Conversion and Management, v.50, n.9, p.2239-2249, 2009. DOI:

https://doi.org/10.1016/j.enconman.2009.05.010

FAO. Food and Agriculture Organization of the United Nations. Crops Data. Roma: FAO, 2018

FAZAL, M. A., HASEEB, A. S. M. A., MASJUKI, H. H. Effect of different corrosion inhibitors on the corrosion of cast iron in palm biodiesel. Fuel Processing Technology, v.92, p.21542159, 2011b. DOI:

https://doi.org/10.1016/j.fuproc.2011.06.012

FAZAL, M. A.; HASEEB, A. S. M. A.; MASJUKI, H. H.. Corrosion mechanism of copper in palm biodiesel. Corrosion Science, v.67, p.50-59, 2013. DOI:

https://doi.org/10.1016/j.corsci.2012.10.006

FAZAL, M. A.; HASEEB, A. S. M. A.; MASJUKI, H. H..

Degradation of automotive materials in palm biodiesel.

Energy, v.40, p.76-83, 2012. DOI:

https://doi.org/10.1016/j.energy.2012.02.026

FAZAL, M. A.; HASEEB, A. S. M. A.; MASJUKI, H. H.. Effect of temperature on the corrosion behavior of mild steel upon exposure to palm biodiesel. Energy, v.36, p.3328-3334, 2011a. DOI: https://doi.org/10.1016/j.energy.2011.03.028

FONTANA, M. G.. Corrosion engineering. 3 ed. New York: McGraw-Hill, 1987.

GENG, O.; YUAN, Y.; LI, F.. Study on the corrosion rate of steel bars in concrete under high humidity conditions. International Journal of Modelling, Identification and Control, v.7, n.2, p.155-159, 2009. DOI: https://doi.org/10.1504/IJMIC.2009.027069

GIWA, S. O.; CHUAH, L. A.; ADAM, N. M.. Fuel properties and rheological behavior of biodiesel from egusi (Colocynthis 
citrullus L.) seed kernel oil. Fuel Processing Technology, v.122, p.42-48, 2014. DOI:

https://doi.org/10.1016/i.fuproc.2014.01.014

GÜLÜM, M.; BILGIN, A.. Density, flash point and heating value variations of corn oil biodiesel-diesel fuel blends. Fuel Processing Technology, v.134, p.456-464, 2015. DOI: https://doi.org/10.1016/j.fuproc.2015.02.026

HASEEB, A. S. M. A.; MASJUKI, H. H.; ANN, L. J.; FAZAL, M. A.. Corrosion characteristics of copper and leaded bronze in palm biodiesel. Fuel Processing Technology, v.91, p.329-334, 2010a. DOI: https://doi.org/10.1016/i.fuproc.2009.11.004

HASEEB, A. S. M. A.; SIA, S. Y.; FAZAL, M. A.; MASJUKI, H. H.. Effect of temperature on tribological properties of palm biodiesel. Energy, v.35, p.1460-1464, 2010b. DOI: https://doi.org/10.1016/i.energy.2009.12.001

HAYASHI, K.. The cosmetic corrosion mechanism and corrosion resistance of zinc alloy coated steel sheet. International Journal of Materials and Product Technology, v.6, n.1, p.9-25, 1991. DOI:

https://doi.org/10.1504/IJMPT.1991.036645

HU, E.; XU, Y.; HU, X.; PAN, L.; JIANG, S.. Corrosion behaviors of metals in biodiesel from rapeseed oil and metanol. Renewable Energy, v. 37, p.371-378, 2012. DOI: https://doi.org/10.1016/i.renene.2011.07.010

KAUL, S.; SAXENA, R. C.; KUMAR, A.; NEGI, M. S.; BHATNAGAR, A. K.; GOYAL, H. B.; GUPTA, A. K.. Corrosion behavior of biodiesel from seed oils of Indian origin on diesel engine parts. Fuel Processing Technology, v.88, p.303-307, 2007. DOI: https://doi.org/10.1016/i.fuproc.2006.10.011

KNOTHE, G.. Dependence of biodiesel fuel properties on the structure of fatty acid alkyl esters. Fuel Processing Technology, v.86, p.1059-1070, 2005. DOI: https://doi.org/10.1016/j.fuproc.2004.11.002

LANG, X.; DALAI, A.; BAKHSHI, N.; REANEY, M.; HERTZ, P.. Preparation and characterization of bio-diesels from various bio-oils, Bioresource Technology, v.80, n.1, p.53-62, 2001. DOI: https://doi.org/10.1016/S0960-8524(01)00051-7

MCCORMICK, R. L.; RATCLIFF, M.; LAWRENCE, R.. Several factors affecting the stability of biodiesel in standard accelerated tests. Fuel Processing Technology, v.88, p. 651657, 2007. DOI:

https://doi.org/10.1016/j.fuproc.2007.01.006

NAUTIYAL, P.; SUBRAMANIAN, K. A.; DASTIDAR, M. G.. Production and characterization of biodiesel from algae. Fuel Processing Technology, v.120, p.79-88, 2014. DOI: https://doi.org/10.1016/i.fuproc.2013.12.003
NOROUZI, S.; ESLAMI, F.; WYSZYNSKI, M. L.; TSOLAKIS, A.. Corrosion effects of RME in blends with ULSD on aluminium and copper. Fuel Processing Technology, v.104, p.204-210, 2012. DOI: https://doi.org/10.1016/j.fuproc.2012.05.016

OKA, J.. Trends in corrosion-resistant precoated steel sheets for automotive applications. International Jounal of Materials and Product Technology, v.1, n.1, p.98-114, 1986. DOI: https://doi.org/10.1504/IJMPT.1986.036757

ÖZTÜRK, E.. Performance, emissions, combustion and injection characteristics of a diesel engine fuelled with canola oil-hazelnut soapstock biodiesel mixture. Fuel Processing Technology, v.129, p.183-191, 2015. DOI: https://doi.org/10.1016/i.fuproc.2014.09.016

PEREIRA, R. G.; OLIVEIRA, C. D.; OLIVEIRA, J. L.; OLIVEIRA, P. C. P.; FELLOWS, C. E.; PIAMBA, O. E.. Exhaust emissions and electric energy generation in a stationary engine using blends of diesel and soybean biodiesel. Renewable Energy, v.32, n.14, p.2453-2460, 2007. DOI:

https://doi.org/10.1016/j.renene.2006.05.007

PEREIRA, R. G.; TULCAN, O. E. P.; FELLOWS, C. E.; LAMEIRA, V. J.; QUELHAS, O. L. G.; AGUIAR, M. E.; SANTO FILHO, D. M. E.. Sustainability and mitigation of greenhouse gases using ethyl beef tallow biodiesel in energy generation. Journal of Cleaner Production, v.29-30, p.269-276, 2012. DOI: https://doi.org/10.1016/i.jclepro.2012.01.007

PEREIRA, R. G.; TULCAN, O. E. P.; FELLOWS, C. E.; SILVA, I. M.; SANTO FILHO, D. M. E.; LAMEIRA, V. J.; QUELHAS, O. L. G.. Energy generation using coconut biodiesel and coconut oil in a stationary engine. International Journal Oil Gas and Coal Technology, v.7, n.4, p.450-473, 2014. DOI: https://doi.org/10.1504/IJOGCT.2014.062165

PEREIRA, R. G.; TULCAN, O. E. P.; LAMEIRA, V. J.; SANTO FILHO, D. M. E.; ANDRADE, E. T.. Use of soybean oil in energy generation. In: KREZHOVA, D.. Recent trends for enhancing the diversity and quality of soybean products. Rijeka: InTech, 2011. p.301-320.

PERES, J. R. R.. Oilseeds for biodiesel: current and potential situation. Brasília: 2006.

SINGH, B.; KORSTAD, J.; SHARMA, Y. C.. A critical review on corrosion of compression ignition $(\mathrm{Cl})$ engine parts by biodiesel and biodiesel blends and its inhibition. Renewable and Sustainable Energy Reviews, v.16, p.3401-3408, 2012. DOI: https://doi.org/10.1016/j.rser.2012.02.042

TAKAO, K.; OGISHI, H.; KIMURA, H.; ICHIDA, T.. Corrosion behaviour of organic composite coated steel sheet. International Journal of Materials and Product Technology, v.6, n.4, p.381-395, 1991. DOI: https://doi.org/10.1504/IJMPT.1991.036643

A CBPC - Companhia Brasileira de Produção Científica (CNPJ: 11.221.422/0001-03) detém os direitos materiais desta publicação. Os direitos referem-se à publicação do trabalho em qualquer parte do mundo, incluindo os direitos às renovações, expansões e disseminações da contribuição, bem como outros direitos subsidiários. Todos os trabalhos publicados eletronicamente poderão posteriormente ser publicados em coletâneas impressas sob coordenação da Sustenere Publishing, da Companhia Brasileira de Produção Científica e seus parceiros autorizados. Os (as) autores (as) preservam os direitos autorais, mas não têm permissão para a publicação da contribuição em outro meio, impresso ou digital, em português ou em tradução. 